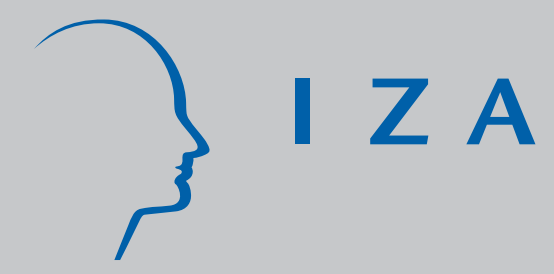

IZA DP No. 3507

Discounting Financial Literacy: Time Preferences and Participation in Financial Education Programs

Stephan Meier

Charles Sprenger

May 2008 


\title{
Discounting Financial Literacy: Time Preferences and Participation in Financial Education Programs
}

\author{
Stephan Meier \\ Federal Reserve Bank of Boston \\ and IZA \\ Charles Sprenger \\ University of California, San Diego \\ Discussion Paper No. 3507 \\ May 2008 \\ IZA \\ P.O. Box 7240 \\ 53072 Bonn \\ Germany \\ Phone: +49-228-3894-0 \\ Fax: +49-228-3894-180 \\ E-mail: iza@iza.org
}

\begin{abstract}
Any opinions expressed here are those of the author(s) and not those of IZA. Research published in this series may include views on policy, but the institute itself takes no institutional policy positions.

The Institute for the Study of Labor (IZA) in Bonn is a local and virtual international research center and a place of communication between science, politics and business. IZA is an independent nonprofit organization supported by Deutsche Post World Net. The center is associated with the University of Bonn and offers a stimulating research environment through its international network, workshops and conferences, data service, project support, research visits and doctoral program. IZA engages in (i) original and internationally competitive research in all fields of labor economics, (ii) development of policy concepts, and (iii) dissemination of research results and concepts to the interested public.
\end{abstract}

IZA Discussion Papers often represent preliminary work and are circulated to encourage discussion. Citation of such a paper should account for its provisional character. A revised version may be available directly from the author. 


\title{
ABSTRACT
}

\section{Discounting Financial Literacy: Time Preferences and Participation in Financial Education Programs*}

\begin{abstract}
Many policy makers and economists argue that financial literacy is key to financial well-being. But why do many individuals remain financially illiterate despite the apparent importance of being financially informed? This paper presents results of a field study linking individual decisions to acquire personal financial information to a critical, and normally unobservable, characteristic: time preferences. We offered a short, free credit counseling and information program to more than 870 individuals. About 55 percent chose to participate. Independently, we elicited time preferences using incentivized choice experiments both for individuals who selected into the program and those who did not. Our results show that the two groups differ sharply in their measured discount factors. Individuals who choose to acquire personal financial information through the credit counseling program discount the future less than individuals who choose not to participate. Our results suggest that individual time preference may explain who will and who will not choose to become financially literate. This has implications for the validity of studies evaluating voluntary financial education programs and policy efforts focused on expanding financial education.
\end{abstract}

JEL Classification: D14, D91, C93

Keywords: $\quad$ financial literacy, time preferences, selection, field experiment

Corresponding author:

Stephan Meier

Research Center for Behavioral Economics and Decision-Making

Federal Reserve Bank of Boston

600 Atlantic Avenue

Boston, MA 02210

USA

E-mail: stephan.meier@bos.frb.org

\footnotetext{
* We are grateful to Daniel Benjamin, Chris Foote, Andreas Fuster, Lorenz Goette, Glenn Harrison, Simon Luechinger, Joanna Stavins, and Alois Stutzer. This paper was previously entitled "Selection into Financial Literacy Programs: Evidence from a Field Study". The views expressed in this paper are those of the authors and not necessarily those of the Federal Reserve System or the Federal Reserve Bank of Boston.
} 


\section{Introduction}

In personal finance, as in other areas of decision-making, information is thought to be a good thing. Financially literate individuals make fewer mistakes and are in better financial condition than financial illiterates (for surveys, see Lusardi and Mitchell, 2007; Bernanke, 2006). Based on the positive association between financial outcomes and financial knowledge, policymakers promote educational programs, such as credit counseling, homeownership classes, and retirement seminars. The fact that the new bankruptcy law in the U.S. requires individuals to undergo credit counseling illustrates the importance that policymakers place on providing information about personal finance. ${ }^{1}$

Despite the apparent importance of financial literacy, many individuals remain financially illiterate. Evidence shows that a large number of individuals lack even basic financial understanding. Individuals generally score poorly on financial literacy exams (see, for example, National Council on Economic Education, 2005; Mandell, 2004) and fail to understand financial instruments (see, John Hancock Financial Services, 2002). ${ }^{2}$ Furthermore, Lusardi and Mitchell (2007) show that only around half of individuals in the Health and Retirement Survey are able to answer two simple questions on inflation and compound interest. It remains an open question why, if acquiring financial information is so critical to financial well-being, many individuals do not choose to become more financially informed.

Very little evidence exists exploring the decision processes underlying the acquisition of financial information. The acquisition of financial information, like voluntary education in general, can be viewed as an investment in human capital. Individuals become financially literate, incurring costs in the present, with an expectation of returns

\footnotetext{
${ }^{1}$ A debtor may be eligible for bankruptcy under Chapter 7 law only if he or she has participated in an approved credit counseling session in the previous 180 days. See 11 U.S.C. $\S \S 109,111$ for details.

${ }^{2}$ For a survey on the state of financial literacy, see Lusardi (2006) and papers cited therein.
} 
on this human capital investment in future periods. As such, time preference should play a role in determining whether or not an individual chooses to acquire personal financial information. Individuals who heavily discount the future should be less likely to invest in financial education than those who don't discount the future as much. In this paper, we test this hypothesis and show that an individual's discount factor is highly correlated with the acquisition of personal financial information.

Our evidence comes from a field study implemented in cooperation with the City of Boston and a large credit counseling firm that offered financial information, in the form of a short credit counseling session, to more than 870 individuals. The counseling session included an overview of the individual's credit report, with their credit score, along with useful credit information. Independently, we elicited the time preferences of all individuals to whom the program was offered, using incentivized choice experiments. The design of the study allows us to correlate measured discount factors with the decision to take-up the offered credit counseling program.

Analyzing the acquisition of financial information in this framework has several advantages. First, the outcome variable (that is, whether individuals choose to receive the counseling session) is an objectively observable behavioral measure. The participation decision does not depend on cognitive or learning abilities (as some financial literacy tests do), and the program is designed to have very low costs for participants (described below). Second, the topic is particularly relevant. Knowledge about credit scoring and one's credit score is very important in the United States for financial decisions, since credit scores are used to determine not only whether one gets a loan, but also the interest rate. In addition, credit reports may legally be used by employers, landlords, and insurance companies in their decision-making (see 15 U.S.C. $§ 1681 b)$.

In the field study, only about 55 percent of individuals chose to receive a free credit score and participate in the short credit counseling session. We show that this 
participation decision is highly correlated with individual time preference; individuals who have higher discount factors are more likely to opt into the program. This result is robust to controlling for a number of socio-demographic characteristics, such as income and education.

Additionally, we show that time preference influences information acquisition prior to receipt of the offer of the small intervention in the field study. More patient individuals are more likely to know what a credit score is. Controlling for this prior information acquisition, however, has little effect on the strong correlation between time preference and the participation decision.

That we find a positive correlation between patience and acquisition of financial information may help to explain why some individuals remain financially illiterate. Financial literacy is an investment in human capital. Those who heavily discount the future will heavily discount the benefit of being financially literate and so will find acquiring financial information not to be an attractive investment.

Our results have at least two further implications. First, our results speak to the presence of selection effects in the evaluation of financial programs. Previous research has found that, in general, more patient individuals have better financial outcomes, since they search longer for a good job (DellaVigna and Paserman, 2005), experience steeper wage growth (Munasinghe and Sicherman, 2006), take up welfare programs earlier (Fang and Silverman, 2006), have higher credit scores, and are less likely to default on their loans (Meier and Sprenger, 2006). This indicates that patient individuals who acquire financial information are already on the path to better outcomes. If the measured effects of financial information interventions do not rely on randomization, then their observed educational effects are most likely overestimated. Because few studies can solve this selection problem ${ }^{3}$ we believe there is very limited unbiased evidence on

\footnotetext{
${ }^{3}$ There are a few notable exceptions. For example, Bernheim et al. (2001) and Cole and Shastry (2007) use changes in state level mandates for financial curriculum in high schools as an identification
} 
whether financial information interventions have a positive effect.

Second, an expansion of voluntary financial programs will continue to miss certain consumers. Voluntary programs are considered by some to be a helpful step in creating better financial outcomes for an increasing number of people (see, for example, Braunstein and Welch, 2002). We suggest not only that the expansion of these programs may reach only a limited number of individuals, but also that such programs will not be attractive to the target population of financial illiterates. If this is the case, policy makers face significant difficulty in addressing financial illiteracy.

The rest of the paper is organized as follows: Section 2 presents the design of the field study and of the choice experiments, Section 3 presents the results, and Section 4 concludes by elaborating on the paper's policy implications.

\section{Design of Field Study}

Our results are based on a unique field study that measures an individual's discount factor regardless of his or her decision to participate in a financial education program, and investigates who selects into the educational program.

\subsection{Design of Financial Education Program}

The study took place at a Volunteer Income Tax Assistance (VITA) site in Roxbury, a neighborhood in Boston, Massachusetts. ${ }^{4}$ Jointly with the City of Boston and a large credit counseling corporation, we offered 872 individuals a free TransUnion \& Co. credit

strategy and come to differing conclusions about the effect of financial education on future savings. Duflo and Saez (2003) offer randomized incentives to participate in a savings seminar and show that the effects, although positive, are extremely small. See also Lusardi and Mitchell (2007) for a survey.

${ }^{4}$ There are currently 23 VITA sites in and around Boston, MA. Coordinated by a city-wide coalition of government and business leaders, VITA sites provide free tax preparation assistance to low-tomoderate income (LMI) households. Taxes are prepared by volunteers throughout tax season, from late January to mid-April each year. 
report (including their Fair Issac Corporation (FICO) score), a short overview of how to read a credit report (for information about credit reports, see Avery et al. (2003)), and several key steps they could take to improve or maintain their credit rating. All tax filers entering the VITA site were offered the short credit session.

The exact procedure in the field study was as follows: first, all taxpayers entering the Roxbury VITA site during the times we conducted the study were asked whether they wanted to receive a free, short credit counseling session (including their credit score) while waiting for a volunteer to help them with their taxes. Participation was almost costless in the sense that we paid for the monetary cost of the credit report; individuals were explicitly informed that the credit report involved was a so-called "soft inquiry" that would not affect their score; and most individuals already had to wait quite a long time at the tax sites for their taxes to be prepared (so opportunity costs of participating were minimal). Furthermore, concerns about identity theft are very unlikely to affect the decision to receive counseling since individuals come to the VITA site voluntarily and entrust all their personal information to the volunteers at the site for tax filing purposes. Individuals could choose to receive the short counseling session at any point in the process.

Second, independent of whether they opted to receive the counseling session, individuals received a preparatory packet with forms for their taxes, a survey with some socio-demographic and other information, and a set of multiple price lists to enable us to measure time preferences.

Third, we explained to all individuals how to fill in the price lists and how the payment mechanism for the price lists would work (more details about the price lists are given below).

Fourth, individuals filled out the surveys and completed the price lists. Those who elected to participate then received a short one-on-one credit counseling session. The 
session lasted no more than 15 minutes, and individuals had been informed of this fact before deciding to participate. Upon completion of the credit counseling session, a tax preparation volunteer helped the individual to file his or her taxes. Individuals who decided to receive the free credit counseling did not lose their place in the line for tax preparation, and all individuals were informed of this in advance.

We acquired the following information for 872 individuals: $(i)$ whether they participated in the short credit counseling program, (ii) a measure of their time preferences, and (iii) their income situation, from their tax filing. Additionally, we obtain information on the day when individuals were offered the financial education program in the VITA site. This enables us to control for day-specific waiting times and potential social interaction effects. (iv) For a substantial number of the individuals in our study, we also have a complete record of the socio-demographic characteristics reported from the preparatory survey mentioned above. This survey included questions on the individual's gender, race, education, whether the individual has at least one credit card, the outstanding balances on all credit cards, information on knowledge of English, whether the individual expects to move in the next seven months, and the individual's willingness to take risks. The survey also includes a question on prior financial knowledge. Individuals were asked: "Do you know what a credit score is?" The answers to this yes/no question are used to determine whether time preferences correlate with information acquisition prior to the field study, and whether inclusion of prior knowledge can explain the association between time preferences and the decision to participate in the credit counseling program.

The average individual in the field study is around 38 years of age, AfricanAmerican, female, has no college experience, annual disposable income of around $\$ 17,000$, and 0.5 dependents (see Column (1) of Table 1). The study therefore focuses on low-to-moderate-income (LMI) individuals. This non-standard subject pool 
is of particular interest for the research question at hand, first, as there are very few experimental studies focusing solely on the behavior of LMI families in developed countries (an exception is Eckel et al., 2005) and, second, as their relatively insecure financial position puts them at great financial risk to health and income shocks (see Bertrand et al., 2004). As Campbell (2006, p. 1554) notes “... for many households, the discrepancies between observed and ideal behavior have relatively minor consequences ...; for a minority of households, particularly poorer and less educated households, there are larger discrepancies with potentially serious consequences."

\subsection{Measuring Time Preferences}

Participants' time preferences were measured with incentivized choice experiments (for similar approaches, see Harrison et al., 2002; McClure et al., 2004; Dohmen et al., 2006; Meier and Sprenger, 2006; Benjamin et al., 2007, and for a survey on measuring time preferences, see Frederick et al. (2002)). Individuals were asked to make 22 choices between a smaller reward $(\$ X<\$ 50)$ in period $t$ and a larger reward $(\$ 50)$ in period $t+\tau>t$. The amount $X$ varied from $\$ 49$ to $\$ 14$. We use three time sets. In two of the price lists, $t$ is the present $(t=0)$ and $\tau$, the delay, is either one month $(\tau=1)$ or six months $(\tau=6)$. In the third price list, $t$ is delayed six months $(t=6)$ and $\tau$ is one month $(\tau=1)$. (See the appendix for the instructions and the multiple price lists.)

The multiple price list setup (see, for example, Harrison et al., 2005) enables us to measure an individual's discount factor $(I D F)^{5}$ for three different time frames by looking at the point, $X^{*}$, at which individuals switch from opting for the smaller, sooner payment to the larger, later payment, in a given price list. That is, a discount factor is taken from the last point at which an individual prefers the sooner, smaller

\footnotetext{
${ }^{5}$ In the paper, we use the individual discount factor $(I D F)$ instead of the individual discount rate $(I D R): I D F=1 /(1+I D R)$.
} 
payment. For example, if an individual prefers $\$ 45$ today over $\$ 50$ in one month, but prefers $\$ 50$ in one month over $\$ 40$ today, we take $\$ 45$ as the switching point and the corresponding monthly discount factor as $0.9 .{ }^{6}$ We use the average across the three choice sets of the calculated monthly discount factors, $\overline{I D F}$, in the main analysis. ${ }^{7}$ We also test for the fact that we elicit an interval and not a point estimation of IDFs (see below). Importantly, the research question at hand needs only a reliable measure of the heterogeneity in $I D F_{\mathrm{s}}$ across individuals and not necessarily precise point estimates of the level of the $I D F$ s.

The order of the three time frames was randomized, and the same three experimenters explained the choices to the subjects. The researchers told the subjects that they were required to choose either the smaller, earlier reward or the larger, later reward for each decision pair. The experimenters also explained that 10 percent of individuals would be randomly paid one of their choices. This was done by giving subjects, at the end of their tax filing, raffle tickets that indicated which choice, if any, would be effective. To ensure credibility of the payments, we filled out money orders for the winning amounts on the spot in the presence of the participants, put them in labeled, pre-stamped envelopes, and sealed the envelopes. The payments were guaranteed by the Federal Reserve Bank of Boston, and individuals were informed that they could always return to the VITA site where the experiment was run to report any problems receiving the payments. ${ }^{8}$ Money orders were sent by mail to the winners' home addresses, either on that day (if $t=0$ ) or in one, six, or seven months, depending on the winner's choice. The payment procedure therefore mimicked a front-end-delay design (Harrison et al., 2005). ${ }^{9}$

\footnotetext{
${ }^{6}$ Therefore, individuals' discount factors are calculated: $I D F^{\tau}=X^{*} / 50$.

${ }^{7} \mathrm{We}$ also test whether $I D F$ s measured in each of the three price lists are associated with becoming informed, and indeed they are.

${ }^{8}$ In fact, one participant returned to the VITA site, almost seven months after the experiment to ask about his payment. He was, however, three days too early, and received the payment on time.

${ }^{9}$ If individuals expect to move in the next seven months, they may question the likelihood of their
} 
Measuring time preferences with incentivized multiple price lists has many advantages over other approaches (Frederick et al., 2002), but the method also has challenges that must be addressed.

First, the price lists do not elicit point estimates of the $I D F$ s but rather ranges of where the IDFs lie (see Coller and Williams, 1999, for details). Especially for individuals who accept the smaller, earlier payment in all choices, the interval will be relatively large, as the subjects might have accepted even lower amounts than offered at the earlier time. To address this issue, we show that the results are robust to estimation with interval regressions (as suggested by Harrison et al., 2005).

Second, individuals' decisions concerning the price lists may be affected by either their outside lending or their outside borrowing opportunities (see Harrison et al., 2005). On the one hand, an individual who can lend at an interest rate higher than the implied interest rate offered in the multiple price list should arbitrage the experiment by taking earlier payments. However, the lowest implied interest rate offered in the choice experiment for $\tau=1$ was 27 percent per year, which is difficult to match in the real world. Some of the interest rates for $\tau=6$ were substantially lower, making it is easier to find more favorable investment opportunities outside the experiment. If outside investment opportunities play a role, individuals should appear more impatient if $\tau=6$ than if $\tau=1$. But individuals exhibit higher (not lower) IDFs if $\tau=$ 6 than if $\tau=1(p<0.001)$. Outside investment opportunities, therefore, do not seem to drive the experimental results. On the other hand, a person who can borrow at a rate lower than the experimentally offered rate should arbitrage the experiment by waiting for later payments. The individual may appear patient while actually arbitraging the experiment by borrowing externally at a lower rate and repaying later

mail being forwarded to their new address in a timely manner. As movers might therefore prefer payments in the present for logistical reasons and not for reasons related to their underlying time preference, we ask individuals "Do you expect to move in the next 7 months?" Including the answer to this question does not affect our results. 
with earnings from the experiment. Because the implied interest rates in the experiment are large (especially in the case of $\tau=1$ ), this is relatively easy to do. However, not many individuals consistently choose the later, larger payments to take advantage of the apparent arbitrage opportunity. Since the implied $I D F \mathrm{~s}$ are rather small and significantly less than one $(p<0.001)$, outside borrowing opportunities do not seem to drive the experimental results.

Third, the measurement of IDFs by observing individuals' switching points in price lists implicitly assumes that utility is linear over the payments in question. This procedure simplifies the analysis considerably and is consistent with expected utility theory, which implies that consumers are approximately risk neutral over small stakes outcomes (Rabin, 2000). However, some researchers have argued that parameters estimated from price lists may also capture differences across individuals in the degree of curvature of the utility function (Andersen et al., 2008). ${ }^{10}$ We therefore test whether differences in risk aversion affect our results using a question on general risk attitudes previously validated with a large, representative sample (Dohmen et al., 2005). The question reads as follows: "How willing are you to take risks in general? (on a scale from 0 "unwilling" to 10 "fully prepared"). While risk aversion is correlated with measured time preferences, it does not affect the results of this paper.

Fourth, in order to measure an $I D F$, an individual must exhibit a unique switching point in each choice set. Around 11 percent do not exhibit a unique switching point in one or more price lists. In the main analysis we focus on the 778 individuals who show a unique switching point in all choice sets. Individuals who have multiple switching points within a choice set are neither more nor less likely to sign up for the counseling sessions. When we include these individuals in a robustness test by taking their first

\footnotetext{
${ }^{10}$ Attributing our experimental responses to risk preferences alone yields unrealistically high levels of risk aversion. For a discussion of the high stakes implications of even moderate risk aversion over small stakes see Rabin (2000).
} 
switching point, the results do not change.

\section{Results}

Of all individuals offered the short credit counseling session, only 55 percent opted to acquire financial information, while the rest declined. The role of individuals' time preferences in this decision is presented in three steps. First, we present descriptive statistics of the difference between participants and non-participants. Second, the direct association between time preferences and the decision to participate in the credit counseling program is investigated in a multivariate regression analysis. Third, we present the association between time preferences and prior financial knowledge and the joint effect of time preferences and prior knowledge on the decision to participate in the program.

\subsection{Descriptive Statistics}

There is a clear difference in time preferences between individuals who select into acquiring information and those who decide not to become informed. Table 1 shows that individuals who choose to participate in the counseling session have an $\overline{I D F}$ of 0.85, compared with an $\overline{I D F}$ of 0.78 for individuals who choose not to participate $(p<0.001) .{ }^{11}$ Figure 1 shows the cumulative distribution of the $\overline{I D F} \mathrm{~s}$ for the two groups. The figure illustrates that individuals who select to acquire information have substantially higher $\overline{I D F}$ s. To put it differently, individuals who selected into credit counseling chose the $\$ 50$ in the future an average of 12 times out of 22 choices, while individuals who selected not to receive counseling chose the larger, later reward only 9 times.

\footnotetext{
${ }^{11}$ We use $t$-tests to compare means until otherwise noted.
} 
[Table 1 and Figure 1 about here]

Table 1 compares other characteristics of the individuals who choose to receive the short counseling session and those who decline the offer. ${ }^{12}$ The comparison of the two self-selected groups shows that they hardly differ in observable basic demographic characteristics. Also, the two groups do not differ in income levels. Therefore, the variables regularly controlled for in evaluation studies of educational programs (demographics and income), do not seem to differ sharply between the two groups.

The two groups, however, differ starkly in both educational level and whether they know what a credit score is. Participants in the educational program are more likely to have college experience $(p<0.01)$ and are more likely to know what a credit score is $(p<0.01)$. Both variables are potentially correlated with time preferences (because their levels reflect investments in human capital) and appear to be correlated with the participation decision. Controlling for education is important, since it could be a proxy for cognitive abilities, which might influence IDFs (Benjamin et al., 2006). To avoid omitted variable bias in our analysis, in the next sections we control for education, whether people knowing what a credit score is and additional control variables.

\subsection{The Effect of Time Preferences on Participation}

As shown in the descriptive statistics, time preferences are highly correlated with the decision to participate in a financial education program. As other factors also correlate with this decision, especially education, in the following analysis we control for sociodemographic variables. Table 2 presents logit regressions where the dependent variable is 1 if the individual participated in the credit counseling program and 0 otherwise. To the basic regression in column (1) we add exogenous demographic characteristics age,

\footnotetext{
${ }^{12}$ The number of observation differs due to availability of information for certain questions. Importantly, even though the number of observations varies depending on the control variables we use, the effect of time preferences on acquiring information remains the same for each sample.
} 
race and gender in column (2); and then in column (3) additional socio-demographic variables education, income and number of dependents, which may be endogenous to an individual's discount factor. In all regressions, we also control for the day individuals were offered the education program.

Column (1) shows the simple association between $\overline{I D F}$ and the counseling participation decision. The marginal effect (not shown) is 0.59 for a change in the $\overline{I D F}$ from 0 to 1 . This means that a change in the $\overline{I D F}$ of one standard deviation increases the probability that a person acquires information by about 10 percentage points. Adding control variables has little effect on this association. The coefficients range from 2.4 to 2.7 , and the respective marginal effects range from 0.59 to 0.66 . Column (2) shows that the effect of $\overline{I D F}$ on the decision to participate in the counseling program holds when controlling for basic demographic characteristics. The probability of acquiring information increases with age and for African-Americans. Column (3) adds additional socio-demographic variables. The results show that, among these additional variables, only education is significantly associated with the decision to acquire information. The relationship between time preferences and counseling participation is, however, little changed by the inclusion of education and income variables.

\section{[Table 2 about here]}

Column (4) in Table 2 extends the list of control variables. The regression controls for whether the individual is a native English speaker, whether he or she expects to move in the next seven months, his or her attitudes toward risk (on a scale from 0, "unwilling," to 10, "fully prepared"), ${ }^{13}$ whether he or she holds at least one credit card, and whether his or her current outstanding balance is greater than $\$ 1,000$. The results in column (4) show that none of the newly added variables is significant. In the

\footnotetext{
${ }^{13}$ The risk measure is treated as a continuous variable. The result does not change, however, if we use dummies for each of the points on the 11-point scale.
} 
remainder of the analysis we do not present results including these additional control variables. The results of each regression, however, are maintained with their inclusion. ${ }^{14}$

As our method of measuring time preferences produces an interval rather than a point estimate of an individual's $I D F$, we test whether the results hold in an interval regression (Stewart, 1983). Table 3 has the interval of IDF as the dependent variable. Column (1) in Table 3 shows that the previous result is also supported in an interval regression. Individuals who participate in the credit counseling program have higher discount factors, i.e. discount the future less. The association remains when we control for socio-demographic characteristics.

[Table 3 about here]

Previous research using interval regression techniques for a representative sample of Danish consumers has shown that some socio-deomographic variables and and the time horizons over which time preferences are elicited correlate with measured discount factors (Harrison et al., 2002). Column (3) of Table 3 allows us to compare whether the same factors correlate with our estimated discount factors for a sample of LMI individuals as those for a representative sample in Denmark (Harrison et al., 2002, : Table 2). The results for the two samples show similar qualitative patterns: the longer the time period, $\tau$, the higher the discount factor; the relationship between age and discount factors is u-shaped; more educated individuals have higher discount factors; and income is positively associated with discount factors. The one notable difference is in the effect of gender. Our results, unlike those of the Danish sample, show that females are significantly more patient than males. In general, however, sociodemographic characteristics seem to have similar effects in both our LMI sample of US consumers and the representative sample of Danish consumers.

\footnotetext{
${ }^{14}$ These results can be obtained from the authors on request.
} 
The result that individuals with higher IDF choose to participate in the credit counseling program is also robust to a number of additional tests. First, the association between IDF and self-selection into credit counseling does not depend on which price list we use to measure individual discount factors. In the main analysis, we take the average, $\overline{I D F}$, but all three separate measures of $I D F$ are strongly associated with the decision to acquire personal financial information (see Table A1 in the appendix). Second, instead of using $\overline{I D F}$ to measure time preferences, we use the number of patient decisions (that is, out of 22 choices, the number of times that the individual opts for $\$ 50$ later) and still find a strong association between information acquisition and individuals' patience (see Table A2 in the appendix). Third, taking individuals' first switching point, the results are robust to including individuals who do not exhibit unique switching points (see Table A3 in the appendix).

In sum, the results show that choosing to receive a credit counseling session is strongly associated with individuals' discount factors. This association holds when controlling for socio-demographic variables and for further characteristics potentially correlated with time preferences. In the following subsection we analyze whether time preferences are also associated with prior financial information acquisition and whether this prior knowledge can explain the relationship between time preference and the decision to acquire information in our field study.

\subsection{Time Preferences and Prior Financial Knowledge}

Time preferences should not only explain who will select into becoming informed in our field study, but also influence the acquisition of personal financial information prior to the field study. To test this claim, we analyze responses to a simple question, in which individuals self-report their knowledge about credit scoring. We create a dummy, Know what score is, which is set equal to 1 for individuals' reporting that they know what 
a credit score is, and 0 otherwise. Of the 568 individuals who answered the question, had non-missing basic control variables, and exhibited a unique switching point in the choice experiments, a substantial share (42 percent) did not know what a credit score is.

[Table 4 about here]

Table 4 presents the association between time preferences and prior financial knowledge, that is, whether individuals know what a credit score is. Column (1) shows results of a regression in which Know what score is is the dependent variable. The results show that $\overline{I D F}$ is associated with prior knowledge. The more patient an individual, that is, the higher an individual's $\overline{I D F}$, the more likely it is that she knows what a credit score is. Not surprisingly, education and income are also substantial predictors of whether individuals know what a score is. Better-educated and wealthier individuals are more likely to know what a score is. The results, therefore, indicate that more patient individuals are more knowledgable about personal finance prior to the field study.

Columns (2) and (3) in Table 4 show the results of regressions in which the dependent variable is the decision to participate in the counseling program. 'Prior financial knowledge' (Know What Score Is) is one of the independent variables. Column (2) shows that without controlling for differences in time preferences, individuals who have prior financial knowledge are more likely to participate in the educational program. Adding $\overline{I D F}$ to the equation does not substantially lower the influence of prior financial knowledge on the decision to participate. More importantly, however, controlling for prior financial knowledge does not substantially change the relationship between time preferences and the decision to acquire information in the field study.

In sum, patient individuals are more likely to acquire financial information through the short credit counseling program offered in the field study and are more knowledgable 
prior to the field study. But given one's prior financial knowledge, time preferences are still important for the decision to acquire further personal financial information.

\section{Discussion and Conclusions}

This paper presents evidence that time preferences strongly matter for whether or not individuals choose to inform themselves about personal finance. In a unique field study, we show that the more individuals discount the future, the lower is the probability that they participate in a short, free financial education program. The result holds when controlling for prior investment in human capital-both general (for example, education) and specific to financial knowledge (for example, knowledge of credit scores).

The paper is able to at least partially answer the question of why, if financial information is so important, many individuals do not become financially literate. If becoming financially literate is an investment in human capital, individuals who heavily

discount the future will be less likely to find the investment to be attractive, and so will remain financially illiterate.

Our results have important implications for the evaluation of financial education programs and voluntary educational programs in general. Self-selection on time preferences in attending financial education programs will affect the results of most program evaluation studies. For example, evidence on the positive effect of credit counseling programs (for example, Elliehausen et al., 2007; Hartarska and Gonzalez-Vega, 2006) are most likely biased upwards. Our results indicate that individuals entering voluntary financial education programs care more about the future than those who decide not to enter. Previous research has shown that these more patient, "treated" individuals are more likely to have improved financial outcomes regardless of whether they participate in education programs. Measured effects of "treatment" are therefore biased and the 
direction of the bias is towards overestimation of positive effects.

Unbiased evidence on the effect of financial educational programs therefore requires randomized treatment. Given the bias noted above, the estimated effects should be expected to be much smaller. In fact, Duflo and Saez (2003) find very small effects in a randomized study. Additional, unbiased studies such as this one are needed to evaluate whether promotion of educational programs will indeed have positive effects on individual financial decision-making.

A second implication concerns efforts to improve financial decisions through educational programs. Our results show that even when participation costs for such programs are minimal, individuals who heavily discount the future choose to not participate, preferring not to invest in financial education. This implies that relying on voluntary educational programs will not greatly affect financial literacy. These programs will likely not be taken up by the target population of financial illiterates.

If, however, significant externalities exist to low levels of individual financial literacy such as higher levels of bankruptcy discharge and low levels of retirement security (the costs of which are at least partially borne by the general public), policy makers may be well founded in desiring individuals to become more financially informed. Concerned policy makers are left with two options: either make financial education mandatory or find a way to alter individual preferences with respect to the acquisition of financial information. Both approaches are problematic.

Making financial education mandatory risks both irritating responsible consumers and having little effect on individuals who would have ignored the offer of financial education had it been voluntary. Furthermore, there is very little evidence as to how, and whether, mandatory programs, like the one introduced in the new U.S. bankruptcy law, work. Bernheim et al. (2001), find that state mandated financial education for high school students does increase future savings. Cole and Shastry (2007) show, however, 
that this result is sensitive both to the data used and the estimation techniques employed. Their findings do not support the conclusion that state mandated financial education increases future savings.

Maybe time preferences are not fixed but can be altered to make the acquisition of financial information a more attractive investment. Becker and Mulligan (1997) argue not only that time preferences influence investment in education, but also that education can influence time preferences by making it easier for individuals to imagine the future. Policy makers appear at times to organize efforts aimed at changing the way people think about the future. As it is unclear and unproven whether time preferences can actually be changed, future research should investigate the relationship between time preferences and abilities like planning and imagination. This will be crucial in order to think about how time preferences are formed and, in turn, how to increase financial information acquisition for all consumers. 


\section{References}

Andersen, Steffen, Glenn W. Harrison, Morten I. Lau, and Elisabet E. Rutstrom, "Eliciting risk and time preferences," Econometrica, 2008, p. Forthcoming.

Avery, Robert B., Raphael W. Bostic, Paul S. Calem, and Glenn G. Canner, "An overview of consumer data and credit reporting," Federal Reserve Bulletin, 2003, 89, $47-73$.

Becker, Gary S. and Casey B. Mulligan, "The endogenous determination of time preferences," Quarterly Journal of Economics, 1997, 112 (3), 729-758.

Benjamin, Daniel, James Choi, and Joshua Strickland, "Social identify and preferences," Working Paper, 2007.

_, Sebastian Brown, and Jesse Shapiro, "Who is 'Behavioral'? Cognitive Ability and Anomalous Preferences," Working Paper, 2006.

Bernanke, Ben, "Financial literacy," Testimony before the Committee on Banking, Housing, and Urban Affairs of the United States Senate on May 232006.

Bernheim, Douglas B., Daniel M. Garrett, and Dean M. Maki, "Education and saving: The long-term effect of high school financial curriculum mandates," Journal of Public Economics, 2001, 80 (3), 435-465.

Bertrand, Marianne, Sendhil Mullainathan, and Eldar Shafir, "A behavioraleconomics view of poverty," American Economic Review, Papers and Proceedings, 2004, $94(2), 419-423$.

Braunstein, Sandra and Carolyn Welch, "Financial literacy: An overview of practice, research, and policy," Federal Reserve Bulletin, 2002, 88 (11), 445-457.

Campbell, John Y., "Household Finance," The Journal of Finance, 2006, 61 (4), 15531604.

Cole, Shawn and Gauri Kartini Shastry, "If You Are So Smart, Why Aren't You Rich? The Effects of Education, Financial Literacy and Cognitive Ability on Financial Market Participation," Working Paper, 2007.

Coller, Maribeth and Melonie B. Williams, "Eliciting individual discount rates," Experimental Economics, 1999, 2, 107-127.

DellaVigna, Stefano and Daniele M. Paserman, "Job search and impatience," Journal of Labor Economics, 2005, 23 (3), 527-588.

Dohmen, Thomas, Armin Falk, David Huffman, and Uwe Sunde, "Dynamic inconsistency predicts self-control problems in humans," Working Paper, 2006.

_, _, , , Juergen Schupp, and Gert G. Wagner, "Individual risk attitudes: New evidence from a large, representative, experimentally-validated survey," Working Paper, 2005. 
Duflo, Esther and Emmanuel Saez, "The role of information and social interaction in retirement plan decisions: Evidence from a randomized experiment," Quarterly Journal of Economics, 2003, 118 (3), 815-841.

Eckel, Catherine C., Cathleen Johnson, and Claude Monmarquette, "Saving decisions of the working poor: Short and long-term horizons," in Jeffrey Carpenter, Glenn W. Harrison, and John A. List, eds., Field Experiments in Economics, Vol. Vol. 10 (Research in Experimental Economics), Greenwich and London: JAI Press, 2005.

Elliehausen, Gregory, E. Christopher Lundquist, and Michael E. Staten, "The impact of credit counseling on subsequent borrower behavior," Journal of Consumer Affairs, 2007, 41 (1), 1-28.

Fang, Hamming and Dan Silverman, "Time-inconsistency and welfare program participation: Evidence from the NLSY," Working Paper, 2006.

Frederick, Shane, George Loewenstein, and Ted O'Donoghue, "Time discounting and time preference: A critical review," Journal of Economic Literature, 2002, 40 (2), $351-401$.

Harrison, Glenn W., Morten I. Lau, and Melonie B. Williams, "Estimating individual discount rates in Denmark: A field experiment," American Economic Review, 2002, 92 (5), 1606-1617.

_, _, Elisabet E. Rutstrom, and Melonie B. Williams, "Eliciting risk and time preferences using field experiments: Some methodological issues," in Jeffrey Carpenter, Glenn W. Harrison, and John A. List, eds., Field experiments in economics, Vol. Vol. 10 (Research in Experimental Economics), Greenwich and London: JAI Press, 2005.

Hartarska, Valentina and Claudio Gonzalez-Vega, "Evidence on the effect of credit counseling on mortage loan default by low-income households," Journal of Housing Economics, 2006, 15 (1), 63-79.

Lusardi, Annamaria, "Financial Literacy and Financial Education: Review and Policy Implications," NFI Policy Brief No. 2006-PB-11, 2006.

_ and Olivia S. Mitchell, "Financial Literacy and Retirenment Preparedness: Evidence and Implications for Financial Education Programs," Business Economics, 2007, January, $35-44$.

Mandell, Lewis, "Financial Literacy: Are We Improving?," Washington, D.C.: JumpStart Coalition for Personal Financial Literacy, 2004.

McClure, Samuel, David Laibson, George Loewenstein, and Jonathan Cohen, "Separate neural systems value immediate and delayed monetary rewards," Science, 2004, $306,503-507$.

Meier, Stephan and Charles Sprenger, "Impatience and credit behavior: Evidence from a field experiment," Working Paper, 2006. 
Munasinghe, Lalith and Nachum Sicherman, "Why dancers smoke? Smoking, time preferences, and wage dynamics," Eastern Economic Journal, 2006, 32 (4), 595-616.

on Economic Education, The National Council, "What American Teens and Adults Know About Economics," Mimeo, 2005.

Rabin, Matthew, "Risk aversion and expected utility theory: A calibration theorem," Econometrica, 2000, 68 (5), 1281-1292.

Services, John Hancock Financial, "Insights into Participant Investment Knowledge and Behavior; Eighth Defined Contribution Plan Survey," Mimeo, 2002.

Stewart, Mark B., "On Least Squares Estimation when the Dependent Variable is Grouped," The Review of Economic Studies, 1983, 50 (4), 737-753. 


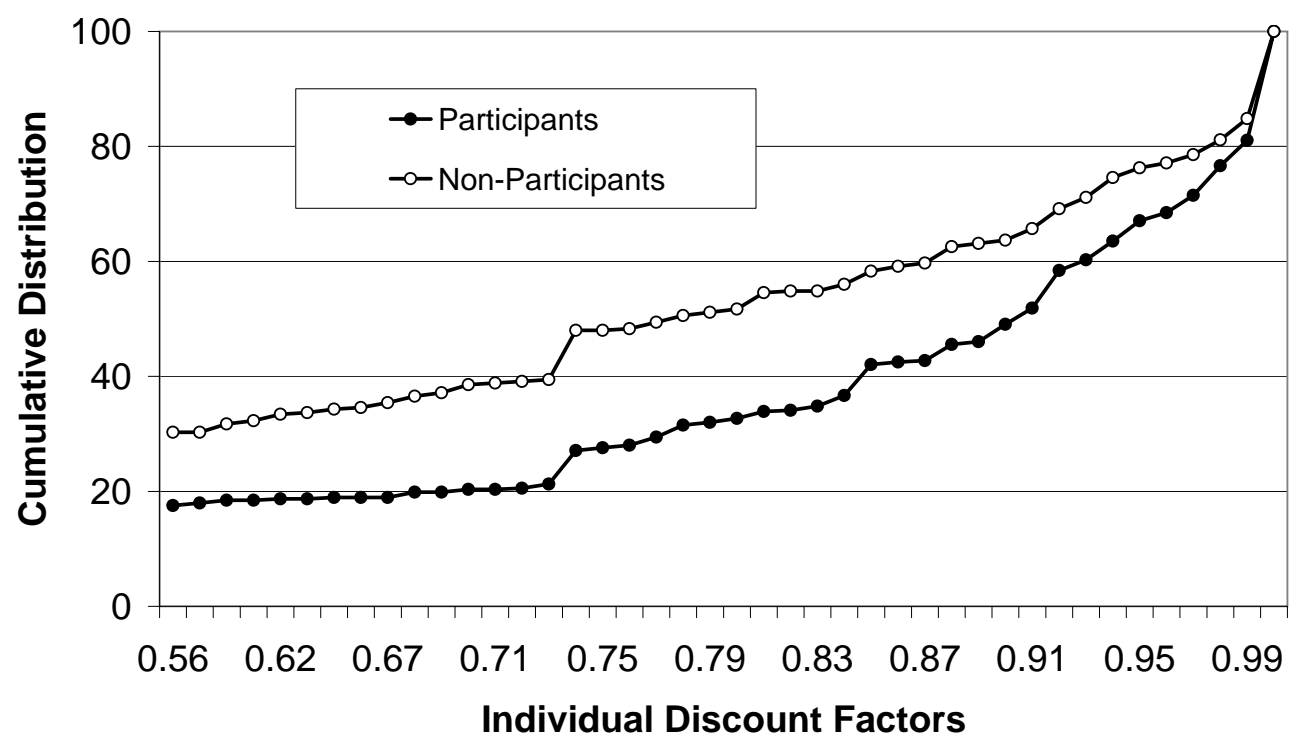

Figure 1: Cumulative Distribution of $\overline{I D F}$ 
Table 1: Summary Statistics

\begin{tabular}{|c|c|c|c|c|}
\hline & $\begin{array}{c}(1) \\
\text { Total }\end{array}$ & $\begin{array}{c}(2) \\
\text { Non-Participants }\end{array}$ & $\begin{array}{c}(3) \\
\text { Participants }\end{array}$ & $t$-tests \\
\hline \multicolumn{5}{|l|}{ Individual Discount Factor } \\
\hline \# of Observations & 778 & 350 & 428 & \\
\hline$\overline{I D F}$ & $\begin{array}{c}0.82 \\
(0.17)\end{array}$ & $\begin{array}{c}0.78 \\
(0.17)\end{array}$ & $\begin{array}{c}0.85 \\
(0.16)\end{array}$ & $p<0.001$ \\
\hline \multicolumn{5}{|l|}{ Basic demographic variables } \\
\hline \# of Observations & 677 & 310 & 367 & \\
\hline Age & $\begin{array}{c}37.74 \\
(14.88)\end{array}$ & $\begin{array}{c}38.81 \\
(16.25)\end{array}$ & $\begin{array}{c}36.83 \\
(13.57)\end{array}$ & $p<0.10$ \\
\hline Race (African-American=1) & $\begin{array}{c}0.77 \\
(0.42)\end{array}$ & $\begin{array}{c}0.74 \\
(0.44)\end{array}$ & $\begin{array}{c}0.80 \\
(0.40)\end{array}$ & $p<0.10$ \\
\hline Gender $($ Female $=1)$ & $\begin{array}{c}0.63 \\
(0.48)\end{array}$ & $\begin{array}{c}0.61 \\
(0.49)\end{array}$ & $\begin{array}{l}0.65 \\
(0.48)\end{array}$ & $p=0.26$ \\
\hline \multicolumn{5}{|c|}{ Additional socio-demographic variables } \\
\hline \# of Observations & 618 & 286 & 332 & \\
\hline College Experience $(=1)$ & $\begin{array}{c}0.45 \\
(0.50)\end{array}$ & $\begin{array}{c}0.36 \\
(0.48)\end{array}$ & $\begin{array}{c}0.52 \\
(0.50)\end{array}$ & $p<0.01$ \\
\hline Adjusted Gross Income & $\begin{array}{c}16,924 \\
(13,759)\end{array}$ & $\begin{array}{c}16,135 \\
(13,926)\end{array}$ & $\begin{array}{c}17,603 \\
(13,600)\end{array}$ & $p=0.19$ \\
\hline Number of Dependents & $\begin{array}{c}0.47 \\
(0.81)\end{array}$ & $\begin{array}{c}0.44 \\
(0.79)\end{array}$ & $\begin{array}{c}0.50 \\
(0.83)\end{array}$ & $p=0.36$ \\
\hline \multicolumn{5}{|l|}{ Prior financial knowledge } \\
\hline \# of Observations & 568 & 255 & 313 & \\
\hline Know What Score Is $(=1)$ & $\begin{array}{c}0.57 \\
(0.49)\end{array}$ & $\begin{array}{c}0.50 \\
(0.50)\end{array}$ & $\begin{array}{c}0.64 \\
(0.48)\end{array}$ & $p<0.01$ \\
\hline
\end{tabular}

Notes: Means for sample with unique switching points in the choice experiments, with nonmissing variables for the respective block of variables plus non-missing variables in the blocks above. Standard errors in parentheses. The last column shows $p$-value for a $t$-test of equal means for participant and non-participant samples. 
Table 2: Time Preferences and Participation in Counseling Program

\begin{tabular}{|c|c|c|c|c|}
\hline & (1) & (2) & (3) & (4) \\
\hline$\overline{I D F}$ & $\begin{array}{l}2.4^{* * *} \\
(.484)\end{array}$ & $\begin{array}{c}2.32^{* * *} \\
(.551)\end{array}$ & $\begin{array}{c}2.36^{* * *} \\
(.603)\end{array}$ & $\begin{array}{c}2.87^{* * *} \\
(.945)\end{array}$ \\
\hline Age & & $\begin{array}{c}.11^{* * * *} \\
(.04)\end{array}$ & $\begin{array}{l}.0807^{*} \\
(.0446)\end{array}$ & $\begin{array}{l}.165^{* *} \\
(.0821)\end{array}$ \\
\hline Age Squared & & $\begin{array}{c}-.001^{* * *} \\
(.0005)\end{array}$ & $\begin{array}{l}-.001^{*} \\
(.0005)\end{array}$ & $\begin{array}{c}-.002^{* *} \\
(.001)\end{array}$ \\
\hline Race & & $\begin{array}{l}.399^{* *} \\
(.199)\end{array}$ & $\begin{array}{l}.46^{* *} \\
(.212)\end{array}$ & $\begin{array}{l}.599^{*} \\
(.317)\end{array}$ \\
\hline Gender $($ Female $=1)$ & & $\begin{array}{l}.185 \\
(.179)\end{array}$ & $\begin{array}{l}.078 \\
(.198)\end{array}$ & $\begin{array}{c}.327 \\
(.326)\end{array}$ \\
\hline College Experience $(=1)$ & & & $\begin{array}{l}.399^{* *} \\
(.195)\end{array}$ & $\begin{array}{l}.12 \\
(.304)\end{array}$ \\
\hline Ln(Income) & & & $\begin{array}{l}.0161 \\
(.0903)\end{array}$ & $\begin{array}{l}.0073 \\
(.137)\end{array}$ \\
\hline \# of Dependents & & & $\begin{array}{l}.0987 \\
(.121)\end{array}$ & $\begin{array}{l}.0229 \\
(.196)\end{array}$ \\
\hline Hold Credit Card $(=1)$ & & & & $\begin{array}{l}.276 \\
(.353)\end{array}$ \\
\hline CC Debt $>\$ 1000$ & & & & $\begin{array}{l}.76 \\
(.496)\end{array}$ \\
\hline Native English (=1) & & & & $\begin{array}{l}-.0326 \\
(.476)\end{array}$ \\
\hline Risk Attitudes & & & & $\begin{array}{r}-.00887 \\
(.0517)\end{array}$ \\
\hline Expect to Move $(=1)$ & & & & $\begin{array}{l}.333 \\
(.327)\end{array}$ \\
\hline Constant & $\begin{array}{c}-1.75^{* * *} \\
(.499)\end{array}$ & $\begin{array}{c}-3.8^{* * *} \\
(.999)\end{array}$ & $\begin{array}{c}-3.77^{* * *} \\
(1.2)\end{array}$ & $\begin{array}{c}-5.06^{* * *} \\
(1.96)\end{array}$ \\
\hline Day dummies & Yes & Yes & Yes & Yes \\
\hline $\begin{array}{l}\text { Log Likelihood } \\
\# \text { of Observations }\end{array}$ & $\begin{array}{c}-488.02 \\
778 \\
\end{array}$ & $\begin{array}{c}-415.61 \\
677 \\
\end{array}$ & $\begin{array}{c}-371.77 \\
618 \\
\end{array}$ & $\begin{array}{c}-371.77 \\
317 \\
\end{array}$ \\
\hline
\end{tabular}

Notes: Dependent variable: Participated in credit counseling program $(=1)$. Logit regressions. Robust standard errors in parentheses.

Level of significance: ${ }^{*} p<0.1,{ }^{* *} p<0.05,{ }^{* * *} p<0.01$. 
Table 3: Time Preferences and Participation in Counseling Program (Interval Regressions)

\begin{tabular}{|c|c|c|c|}
\hline & (1) & (2) & (3) \\
\hline Participate in Program $(=1)$ & $\begin{array}{c}.096 * * * \\
(.017)\end{array}$ & $\begin{array}{c}.076^{* * *} \\
(.018)\end{array}$ & $\begin{array}{c}.073^{* * *} \\
(.018)\end{array}$ \\
\hline Delta Time $(\tau=6)$ & $\begin{array}{c}.033^{* * *} \\
(.001)\end{array}$ & $\begin{array}{c}.033^{* * *} \\
(.001)\end{array}$ & $\begin{array}{c}.033^{* * *} \\
(.001)\end{array}$ \\
\hline Has Present $(t=0)$ & $\begin{array}{c}-.074^{* * *} \\
(.009)\end{array}$ & $\begin{array}{c}-.078^{* * *} \\
(.009)\end{array}$ & $\begin{array}{c}-.081^{* * *} \\
(.010)\end{array}$ \\
\hline Age & & $\begin{array}{l}-.004 \\
(.003)\end{array}$ & $\begin{array}{c}-.011^{* * *} \\
(.004)\end{array}$ \\
\hline Age Squared & & $\begin{array}{c}.00002 \\
(.00004)\end{array}$ & $\begin{array}{c}.0001^{*} \\
(.00005)\end{array}$ \\
\hline Race & & $\begin{array}{l}-.010 \\
(.019)\end{array}$ & $\begin{array}{l}-.009 \\
(.019)\end{array}$ \\
\hline Gender $($ Female $=1)$ & & $\begin{array}{c}.085^{* * *} \\
(.018)\end{array}$ & $\begin{array}{c}.067^{* * *} \\
(.019)\end{array}$ \\
\hline College Experience $(=1)$ & & & $\begin{array}{l}.048 * * \\
(.019)\end{array}$ \\
\hline Ln(Income) & & & $\begin{array}{l}.023^{* *} \\
(.009)\end{array}$ \\
\hline \# of Dependents & & & $\begin{array}{l}.023^{*} \\
(.012)\end{array}$ \\
\hline Constant & $\begin{array}{c}.663^{* * *} \\
(.016)\end{array}$ & $\begin{array}{l}.73^{* * *} \\
(.076)\end{array}$ & $\begin{array}{c}.623^{* * *} \\
(.103)\end{array}$ \\
\hline Day dummies & Yes & Yes & Yes \\
\hline $\begin{array}{l}\text { Log Pseudolikelihood } \\
\text { \# of Observations } \\
\text { \# of Individuals }\end{array}$ & $\begin{array}{c}-6556.46 \\
2,334 \\
778\end{array}$ & $\begin{array}{c}-5692.29 \\
2,031 \\
677\end{array}$ & $\begin{array}{c}-5024.99 \\
1,854 \\
618\end{array}$ \\
\hline
\end{tabular}

Notes: Interval regressions (Stewart, 1983). Standard errors clustered on individual level in parentheses.

Dependent variable: Interval of $I D F$. The interval of $I D F$ is calculated as follows (see also, Harrison et al., 2002): For each of the three price lists and for each individual, we observe a range of possible $I D F$ s from $I D F_{l o w}$ to $I D F_{h i g h}$. This results in three interval observations per individual. We control for the differences in $t$ and $\tau$ of the underlying price lists using the variables Delta Time and Has Present which indicate whether the price list involves a time delay of six months and whether the price list involves the present, respectively.

Level of significance: ${ }^{*} p<0.1,{ }^{* *} p<0.05,{ }^{* * *} p<0.01$. 
Table 4: Time Preferences, Prior Knowledge, and Participation in Counseling Program

\begin{tabular}{lccc}
\hline & $(1)$ & $(2)$ & $(3)$ \\
\hline Dependent variable & Know what score is & \multicolumn{2}{c}{ Participation } \\
\hline$\overline{I D F}$ & $1.13^{* *}$ & & $2.12^{* * *}$ \\
& $(.566)$ & & $(.636)$ \\
Know What Score Is $(=1)$ & & $.394^{* *}$ & $.345^{*}$ \\
& & $(.194)$ & $(.197)$ \\
Age & .003 & .053 & .069 \\
& $(.037)$ & $(.049)$ & $(.054)$ \\
Age Squared & $-6.58 \mathrm{e}-06$ & -.0007 & -.0008 \\
& $(.0004)$ & $(.0006)$ & $(.0007)$ \\
Race & .033 & $.434^{* *}$ & $.466^{* *}$ \\
& $(.209)$ & $(.218)$ & $(.221)$ \\
Gender (Female=1) & $.632^{* * *}$ & .142 & .0464 \\
& $(.197)$ & $(.203)$ & $(.211)$ \\
College Experience $(=1)$ & $.981^{* * *}$ & .312 & .242 \\
& $(.194)$ & $(.206)$ & $(.209)$ \\
Ln(Income) & $.18^{* *}$ & .080 & .042 \\
& $(.091)$ & $(.092)$ & $(.095)$ \\
$\#$ of Dependents & -.0552 & .168 & .128 \\
& $(.124)$ & $(.124)$ & $(.128)$ \\
Constant & $-3.2^{* * *}$ & $-2.03^{*}$ & $-3.61^{* * *}$ \\
& $(1.03)$ & $(1.14)$ & $(1.3)$ \\
Day dummies & No & Yes & Yes \\
\hline Log Likelihood & -353.82 & -345.40 & -339.78 \\
$\#$ of Observations & 568 & 568 & 568 \\
\hline
\end{tabular}

Notes: Logit regressions. Standard errors in parentheses.

Dependent variables: Column(1): Knows what a credit score is $(=1)$; Column (2) and (3): Participated in credit counseling program $(=1)$.

Level of significance: ${ }^{*} p<0.1,{ }^{* *} p<0.05,{ }^{* * *} p<0.01$. 


\section{A Appendix}

\section{A.1 Instructions}

As a tax filer at this Volunteer Income Tax Assistance site you are automatically entered in a raffle in which you could win up to $\$ 50$. Just follow the directions below:

How It Works: In the boxes below you are asked to choose between smaller payments closer to today and larger payments further in the future. For each row, choose one payment: either the smaller, sooner payment or the later, larger payment. When you return this completed form, you will receive a raffle ticket. If you are a winner, the raffle ticket will have a number on it from 1 to 22 . These numbers correspond to the numbered choices below. You will be paid your chosen payment. The choices you make could mean a difference in payment of more than $\$ 35$, so CHOOSE CAREFULLY!!!

RED BLOCK (Numbers 1 through 7): Decide between payment today and payment in one month BLACK BLOCK (Numbers 8 through 15): Decide between payment today and payment in six months

BLUE BLOCK (Numbers 16 through 22): Decide between payment in six months and payment in seven months

Rules and Eligibility: For each possible number below, state whether you would like the earlier, smaller payment or the later, larger payment. Only completed raffle forms are eligible for the raffle. All prizes will be sent to you by normal mail and will be paid by money order. One out of ten raffle tickets will be a winner. You can obtain your raffle ticket as soon as your tax filing is complete. You may not participate in the raffle if you are associated with the EITC campaign (volunteer, business associate, etc.) or an employee (or relative of an employee) of the Federal Reserve Bank of Boston or the Federal Reserve System.

[Red Block; $t=0, \tau=1]$

TODAY VS. ONE MONTH FROM TODAY WHAT WILL YOU DO IF YOU GET A NUMBER BETWEEN 1 AND 7? Decide for each possible number if you would like the smaller payment for sure today or the larger payment for sure in one month? Please answer for each possible number (1) through (7) by filling in one box for each possible number.

Example: If you prefer $\$ 49$ today in Question 1 mark as follows: $\checkmark \$ 49$ today or $\$ 50$ in one month If you prefer $\$ 50$ in one month in Question 1, mark as follows: $\$ 49$ today or $\checkmark \$ 50$ in one month If you get number (1): Would you like to receive $\$ 49$ today or $\$ 50$ in one month If you get number (2): Would you like to receive $\$ 47$ today or $\$ 50$ in one month If you get number (3): Would you like to receive $\$ 44$ today or $\$ 50$ in one month If you get number (4): Would you like to receive $\$ 40$ today or $\$ 50$ in one month If you get number (5): Would you like to receive $\$ 35$ today or $\$ 50$ in one month If you get number (6): Would you like to receive $\$ 29$ today or $\$ 50$ in one month If you get number (7): Would you like to receive $\$ 22$ today or $\$ 50$ in one month

[Black Block; $t=0, \tau=6$ ]

TODAY VS. SIX MONTHS FROM TODAY WHAT WILL YOU DO IF YOU GET A NUMBER BETWEEN 8 AND 15? Now, decide for each possible number if you would like the smaller payment for sure today or the larger payment for sure in six months? Please answer each possible number (8) through (15) by filling in one box for each possible number.

If you get number (8): Would you like to receive $\$ 49$ today or $\$ 50$ in six months

If you get number (9): Would you like to receive $\$ 47$ today or $\$ 50$ in six months If you get number (10): Would you like to receive $\$ 44$ today or $\$ 50$ in six months If you get number (11): Would you like to receive $\$ 40$ today or $\$ 50$ in six months If you get number (12): Would you like to receive $\$ 35$ today or $\$ 50$ in six months If you get number (13): Would you like to receive $\$ 29$ today or $\$ 50$ in six months If you get number (14): Would you like to receive $\$ 22$ today or $\$ 50$ in six months 
If you get number (15): Would you like to receive $\$ 14$ today or $\$ 50$ in six months

[Blue Block; $t=6, \tau=1$ ]

SIX MONTHS FROM TODAY VS. SEVEN MONTHS FROM TODAY WHAT WILL YOU DO IF YOU GET A NUMBER BETWEEN 16 AND 22? Decide for each possible number if you would like the smaller payment for sure in six months or the larger payment for sure in seven months? Please answer for each possible number (16) through (22) by filling in one box for each possible number.

If you get number (16): Would you like to receive $\$ 49$ in six months or $\$ 50$ in seven months If you get number (17): Would you like to receive $\$ 47$ in six months or $\$ 50$ in seven months If you get number (18): Would you like to receive $\$ 44$ in six months or $\$ 50$ in seven months If you get number (19): Would you like to receive $\$ 40$ in six months or $\$ 50$ in seven months If you get number (20): Would you like to receive $\$ 35$ in six months or $\$ 50$ in seven months If you get number (21): Would you like to receive $\$ 29$ in six months or $\$ 50$ in seven months If you get number (22): Would you like to receive $\$ 22$ in six months or $\$ 50$ in seven months 


\section{A.2 Appendix tables}

Table A1: IDF from Each Time Frame and Participation in Counseling Program

\begin{tabular}{|c|c|c|c|}
\hline & (1) & $(2)$ & $(3)$ \\
\hline$I D F_{t=0, \tau=1}$ & $\begin{array}{c}1.27^{* * *} \\
(.409)\end{array}$ & & \\
\hline$I D F_{t=0, \tau=6}$ & & $\begin{array}{c}3.64^{* * *} \\
(1.18)\end{array}$ & \\
\hline$I D F_{t=6, \tau=1}$ & & & $\begin{array}{c}1.72^{* * *} \\
(.418)\end{array}$ \\
\hline Age & $\begin{array}{l}.072^{*} \\
(.043)\end{array}$ & $\begin{array}{l}.075^{*} \\
(.043)\end{array}$ & $\begin{array}{l}.082^{*} \\
(.045)\end{array}$ \\
\hline Age Squared & $\begin{array}{l}-.0009^{*} \\
(.0005)\end{array}$ & $\begin{array}{l}-.001^{*} \\
(.0005)\end{array}$ & $\begin{array}{l}-.001^{*} \\
(.0005)\end{array}$ \\
\hline Race & $\begin{array}{l}.469 * * \\
(.212)\end{array}$ & $\begin{array}{l}.433^{* *} \\
(.211)\end{array}$ & $\begin{array}{l}.447^{* *} \\
(.212)\end{array}$ \\
\hline Gender $($ Female $=1)$ & $\begin{array}{c}.103 \\
(.196)\end{array}$ & $\begin{array}{l}.108 \\
(.196)\end{array}$ & $\begin{array}{c}.102 \\
(.196)\end{array}$ \\
\hline College Experience $(=1)$ & $\begin{array}{l}.432^{* *} \\
(.194)\end{array}$ & $\begin{array}{l}.438^{* *} \\
(.195)\end{array}$ & $\begin{array}{l}.392^{* *} \\
(.195)\end{array}$ \\
\hline Ln(Income) & $\begin{array}{l}.0265 \\
(.090)\end{array}$ & $\begin{array}{l}.031 \\
(.089)\end{array}$ & $\begin{array}{l}.0233 \\
(.089)\end{array}$ \\
\hline \# of Dependents & $\begin{array}{c}.129 \\
(.119)\end{array}$ & $\begin{array}{l}.113 \\
(.119)\end{array}$ & $\begin{array}{c}.079 \\
(.122)\end{array}$ \\
\hline Constant & $\begin{array}{c}-2.79 * * \\
(1.12)\end{array}$ & $\begin{array}{c}-5.24^{* * *} \\
(1.57)\end{array}$ & $\begin{array}{c}-3.26^{* * *} \\
(1.15)\end{array}$ \\
\hline Day dummies & Yes & Yes & Yes \\
\hline $\begin{array}{l}\text { Log Likelihood } \\
\text { \# of Observations }\end{array}$ & $\begin{array}{c}-374.79 \\
618\end{array}$ & $\begin{array}{c}-374.88 \\
618\end{array}$ & $\begin{array}{c}-371.26 \\
618\end{array}$ \\
\hline
\end{tabular}

Notes: Dependent variable: Participated in credit counseling program $(=1)$. Logit regressions. Robust standard errors in parentheses. Level of significance: ${ }^{*} p<0.1,{ }^{* *} p<0.05,{ }^{* * *} p<0.01$. 
Table A2: Participation in Counseling Program and \# of Patient Choices

\begin{tabular}{|c|c|c|c|}
\hline & (1) & $(2)$ & $(3)$ \\
\hline \# of Patient Choices & $\begin{array}{c}.0418^{* * *} \\
(.0103)\end{array}$ & $\begin{array}{c}.0405^{* * *} \\
(.0116)\end{array}$ & $\begin{array}{c}.0404^{* * *} \\
(.0128)\end{array}$ \\
\hline Age & & $\begin{array}{l}.107^{* * *} \\
(.0396)\end{array}$ & $\begin{array}{l}.0759^{*} \\
(.0438)\end{array}$ \\
\hline Age Squared & & $\begin{array}{c}-.00141^{* * *} \\
(.000488)\end{array}$ & $\begin{array}{c}-.000961^{*} \\
(.00053)\end{array}$ \\
\hline Race & & $\begin{array}{l}.398^{* *} \\
(.199)\end{array}$ & $\begin{array}{l}.453^{* *} \\
(.213)\end{array}$ \\
\hline Gender $($ Female $=1)$ & & $\begin{array}{l}.212 \\
(.178)\end{array}$ & $\begin{array}{l}.0995 \\
(.197)\end{array}$ \\
\hline College Experience $(=1)$ & & & $\begin{array}{l}.427^{* *} \\
(.195)\end{array}$ \\
\hline Ln(Income) & & & $\begin{array}{l}.0193 \\
(.09)\end{array}$ \\
\hline \# of Dependents & & & $\begin{array}{l}.107 \\
(.12)\end{array}$ \\
\hline Constant & $\begin{array}{l}-.256 \\
(.337)\end{array}$ & $\begin{array}{c}-2.28^{* * *} \\
(.844)\end{array}$ & $\begin{array}{c}-2.21^{* *} \\
(1.07)\end{array}$ \\
\hline Day dummies & Yes & Yes & Yes \\
\hline $\begin{array}{l}\text { Log Likelihood } \\
\text { \# of Observations }\end{array}$ & $\begin{array}{c}-492.10 \\
778\end{array}$ & $\begin{array}{c}-419.22 \\
677\end{array}$ & $\begin{array}{c}-374.33 \\
618\end{array}$ \\
\hline
\end{tabular}

Notes: Dependent variable: Participated in credit counseling program $(=1)$. Logit regressions. Robust standard errors in parentheses.

Level of significance: ${ }^{*} p<0.1,{ }^{* *} p<0.05,{ }^{* * *} p<0.01$. 
Table A3: $\overline{I D F}$ and Participation in Counseling Program (Including Multiple Switchers)

\begin{tabular}{lccc}
\hline & $(1)$ & $(2)$ & $(3)$ \\
\hline$\overline{I D F}$ & $2.24^{* * *}$ & $2.18^{* * *}$ & $2.2^{* * *}$ \\
Age & $(.46)$ & $(.524)$ & $(.563)$ \\
& & $.070^{* *}$ & .043 \\
Age Squared & & $(.033)$ & $(.039)$ \\
& & $-.0009^{* *}$ & -.0005 \\
Race & & $(.0004)$ & $(.0005)$ \\
& & $.361^{*}$ & $.439^{* *}$ \\
Gender (Female=1) & & $(.188)$ & $(.203)$ \\
& .189 & .067 \\
College Experience $(=1)$ & & $(.167)$ & $(.186)$ \\
& & & $.435^{* *}$ \\
Ln(Income) & & & $(.185)$ \\
& & & .0147 \\
\# of Dependents & & & $(.082)$ \\
& & .128 \\
Constant & $-1.82^{* * *}$ & $-3.13^{* * *}$ & $-3.137^{* * *}$ \\
& $(.482)$ & $(.855)$ & $(1.09)$ \\
Day dummies & Yes & Yes & Yes \\
\hline Log Likelihood & -552.08 & -470.38 & -421.28 \\
\# of Observations & 872 & 751 & 687 \\
\hline
\end{tabular}

Notes: Dependent variable: Participated in credit counseling program $(=1)$. Logit regressions. Robust standard errors in parentheses. Level of significance: ${ }^{*} p<0.1,{ }^{* *} p<0.05,{ }^{* * *} p<0.01$. 